Article

\title{
Mercerization Optimization of Bamboo (Bambusa vulgaris) Fiber-Reinforced Epoxy Composite Structures Using a Box-Behnken Design
}

\author{
Mohamad Zaki Hassan 1,*(1), Siti Amni Roslan ${ }^{2}$, S. M. Sapuan ${ }^{3,4}$, Zainudin A. Rasid ${ }^{2}$, \\ Ariff Farhan Mohd Nor ${ }^{2}$ (D), Mohd Yusof Md Daud ${ }^{1}$, Rozzeta Dolah $^{1}$ (D) and \\ Mohd Zuhri Mohamed Yusoff ${ }^{3}$ (D) \\ 1 Razak Faculty of Technology and Informatics, Universiti Teknologi Malaysia, Kuala Lumpur, Jalan Sultan \\ Yahya Petra, Kuala Lumpur 54100, Malaysia; yusof.kl@utm.my (M.Y.M.D.); rozzeta.kl@utm.my (R.D.) \\ 2 Malaysia-Japan International Institute of Technology, Universiti Teknologi Malaysia, Kuala Lumpur, Jalan \\ Sultan Yahya Petra, Kuala Lumpur 54100, Malaysia; amnihusna90@gmail.com (S.A.R.); \\ arzainudin.kl@utm.my (Z.A.R.); ariffmdnor@yahoo.com (A.F.M.N.) \\ 3 Advanced Engineering Materials and Composites Research Centre, Department of Mechanical and \\ Manufacturing Engineering, Universiti Putra Malaysia, Serdang 43400 UPM, Malaysia; \\ sapuan@upm.edu.my (S.M.S.); zuhri@upm.edu.my (M.Z.M.Y.) \\ 4 Laboratory of Biocomposite Technology, Institute of Tropical Forestry and Forest Products (INTROP) \\ Universiti Putra Malaysia, Serdang 43400 UPM, Malaysia \\ * Correspondence: mzaki.kl@utm.my
}

Received: 14 May 2020; Accepted: 15 June 2020; Published: 17 June 2020

\begin{abstract}
The objective of this research is to optimize the alkaline treatment variables, including sodium hydroxide $(\mathrm{NaOH})$ concentration, soaking, and drying time, that influence the mechanical behavior of bamboo fiber-reinforced epoxy composites. In this study, a Box-Behnken design (BBD) of the response surface methodology (RSM) was employed to design an experiment to investigate the mercerization effect of bamboo fiber-reinforced epoxy composites. The evaluation of predicted tensile strength as a variable parameter of bamboo fiber (Bambusa vulgaris) reinforced epoxy composite structures was determined using analysis of variance (ANOVA) of the quadratic model. In this study, a total of 17 experiment runs were measured and a significant regression for the coefficient between the variables was obtained. Further, the triangular and square core structures made of treated and untreated bamboo fiber-reinforced epoxy composites were tested under compressive loading. It was found that the optimum mercerization condition lies at $5.81 \mathrm{wt} . \%$ of the $\mathrm{NaOH}$, after a soaking time of $3.99 \mathrm{~h}$ and a drying time of $72 \mathrm{~h}$. This optimum alkaline treatment once again had a great effect on the structures whereby all the treated composite cores with square and triangular structures impressively outperformed the untreated bamboo structures. The treated triangular core of bamboo reinforced composites gave an outstanding performance compared to the treated and untreated square core composite structures for compressive loading and specific energy absorbing capability.
\end{abstract}

Keywords: alkaline treatment; optimization; bamboo fibers; response surface methodology

\section{Introduction}

Natural fiber-reinforced composites have been utilized as reinforcements to replace glass and carbon fiber-reinforced composites for various applications, ranging from sports equipment to advanced aerospace structures, due to their unique characteristics, including biodegradability, high specific strength-to-weight ratio, good acoustic resistance, good sustainability, good abrasion resistance, and outstanding energy absorption [1-3]. Many attempts have been made in order to improve the 
properties of composites including the use of natural fiber as a single fibrous nanocomposite for filling in the polymer matrix. Enayati et al. [4] successfully used an electrospinning technique to disperse a wheat straw cellulose nanofiber in polyvinyl alcohol. This matrix modification approach has proved that the Young's modulus of the composite was significantly increased by over six times that of the neat polymer [5].

Natural fiber-based composites are mainly limited to non-structural applications by the incompatible behavior between the natural fiber and the synthetic polymer matrix due to a hydrophobic interaction with the hydrophilic cellulose. In order to combat this issue, the fiber surface of a natural fiber can be modified using chemical treatment. Alkalization, acetylation, benzoylation, bleaching, and silane treatment are frequently used for chemical surface modification of the natural fiber surface. Alkaline treatment, known as the mercerization technique, involves the immersion of natural fibers in concentrated sodium hydroxide $(\mathrm{NaOH})$ solution and has been considered as one of the most popular and cost-effective methods. Here, $\mathrm{NaOH}$ reacts with the hydroxyl group of the natural fibers to remove the cementing materials, including hemicellulose, lignin, wax, and oils, that surround the external surface of the fiber leading to an increase in the surface roughness and fiber-matrix bonding interactions.

Many studies have proven that the chemical modification of natural fibers can increase the mechanical properties of the composite, fiber-matrix adhesion, and compatibility of the natural fiber. Several types of natural fibers, such as kenaf [6], banana [7], and sugar palm [8], were treated using this method and improved the thermal, impact, and barrier properties of fibers in various thermoset and thermoplastic matrices. Khan et al. [9] studied the effect of $\mathrm{NaOH}$ concentration on bamboo fiber-reinforced epoxy composites examining tensile strength and Mode I fracture behavior. They found that treatment of bamboo fibers with $6 \mathrm{wt}$.\% concentration $\mathrm{NaOH}$ offers the highest ultimate tensile strength and maximum Mode-I plane strain fracture toughness $\left(\mathrm{K}_{\mathrm{IC}}\right)$ of the composite laminate. In addition, Cai et al. [10] immersed abaca fibers in 5, 10, and $15 \mathrm{wt} . \% \mathrm{NaOH}$ solutions for $2 \mathrm{~h}$, and evaluated the effects of the alkali treatments on the mechanical characteristics and interfacial adhesion of the abaca fiber/epoxy composite. They suggested that $5 \mathrm{wt} . \% \mathrm{NaOH}$ treatment of abaca fibers increases their crystallinity, tensile strength and Young's modulus compared to untreated fibers, as well as improving the fiber/epoxy interfacial shear strength. The effects of alkali treatment and elevated temperature on the mechanical properties of bamboo fiber-reinforced composites were conducted by Manalo et al. [11]. The bamboo fibers were treated with between 4 and $8 \mathrm{wt} . \% \mathrm{NaOH}$ and then randomly oriented in a polyester matrix. Here, an optimum $\mathrm{NaOH}$ concentration of $6 \mathrm{wt.} \%$ was suggested to give the highest mechanical properties. In contrast, Rao et al. [12] suggested that $1 \%$ concentration of $\mathrm{NaOH}$ is the optimum condition to treat a bamboo polymeric composite. On the other hand, Nirmal et al. [13] claimed that a $6 \mathrm{wt} . \% \mathrm{NaOH}$ concentration is best for treating natural fiber and capable of removing excess moisture thoroughly whilst exhibiting excellent interfacial adhesion strength. However, evidence that the $\mathrm{NaOH}$ concentration alone is the factor that affects the bonding between a matrix and a natural fiber is still inconsistent.

Recently, researchers have shown an increased interest in determination of the optimum condition for alkaline treatment of the natural fiber by using optimization tools. Vardhini et al. [14] optimized the lignin removal from banana fiber with different concentrations of $\mathrm{NaOH}$, time and temperature at three levels using Box-Behnken experimental design. The optimum conditions for lignin decomposition are identified as alkali concentration $11 \mathrm{~g} / \mathrm{L}$, treatment time of $150 \mathrm{~min}$, and temperature at $90^{\circ} \mathrm{C}$. Response surface methodology (RSM) was also employed by Kim et al. [15] to optimize alkaline pre-treatment conditions for maximum glucose yield from rice straw with respect to $\mathrm{NaOH}$ concentration $(1.0-4.0 \%)$, reaction temperature $\left(60-100{ }^{\circ} \mathrm{C}\right)$, and pre-treatment time (30-90 $\left.\mathrm{min}\right)$. The maximum glucose yield of $254.5 \pm 1.2 \mathrm{~g} \mathrm{~kg}^{-1}$ biomass was obtained at the optimum treatment condition of $2.96 \%, 81.79{ }^{\circ} \mathrm{C}$, and $56.66 \mathrm{~min}$. The ANOVA test revealed that the model and all independent parameters were considered statistically significant at $95 \%$ confidence level. Furthermore, Singh et al. [16] used a three-level Box-Behnken design (BBD) method to optimize the mass fraction of fibers, the percentage of crosslinking and the plasticizing agent. Initially, they treated the sugarcane 
bagasse fiber with $6 \mathrm{wt} . \%$ sodium hydroxide. The model predicts that the optimum condition for maximum tensile strength is archived with a matrix content of $11 \%$ glyoxal, $17.7 \%$ glycerol, and $51.3 \%$ soy protein isolate by weight.

In this study, the variables that usually impact on the chemical treatment of bamboo, such as concentration of $\mathrm{NaOH}$, soaking time and drying period are selected. To obtain the optimum values for these parameters, a study using a Box-Behnken design (BBD) for the response surface methodology was employed. The tensile behavior is determined as a function of $\mathrm{NaOH}$ concentration, soaking time and drying period; then a quadratic function equation is proposed. Further, the compression behavior of triangular and square bamboo/epoxy composite core structure were evaluated.

\section{Materials and Methods}

Initially, BBD was used to develop an experimental design for the alkaline treatment conditions for bamboo fibers. The treatment conditions consist of three selected variables: including sodium hydroxide $(\mathrm{NaOH})$ concentration, soaking, and drying time. The design points for each variable in combinations of the high, middle, and low factor levels are derived from Design-Expert (6.0.11) software (Stat-Ease Inc., Minneapolis, MN, USA).

\subsection{Design of the Experiment}

The selection of factor levels for the $\mathrm{NaOH}$ concentration $\left(X_{1}\right)$, soaking period $\left(X_{2}\right)$, and time for bamboo to dry $\left(\mathrm{X}_{3}\right)$ are described as follows:

$$
\begin{gathered}
3 \text { wt. } \% \leq \mathrm{NaOH} \text { concentration }\left(\mathrm{X}_{1}\right) \leq 9 \text { wt.\% } \\
3 \mathrm{~h} \leq \text { soaking time }\left(\mathrm{X}_{2}\right) \leq 9 \mathrm{~h} \\
24 \mathrm{~h} \leq \operatorname{drying} \text { time }\left(\mathrm{X}_{3}\right) \leq 72 \mathrm{~h}
\end{gathered}
$$

Table 1 tabulates the coded and actual levels of the determining variables in this study. The relationship between the coded values and actual values is described in Equation (1).

$$
x_{i}=\frac{X_{i}-X_{o}}{\Delta X_{i}} i=1,2,3
$$

where $x_{i}$ and $X_{i}$ are the coded and actual values of the independent variable, respectively. $X_{o}$ is the actual value of the independent variable at the middle level, and $\Delta X_{i}$ is the step change of $X_{i}$. Then, the input data of Table 1 are randomized and modelled by BBD.

Table 1. The proposed variable values by the Box-Behnken Design-expert (6.0.11) software.

\begin{tabular}{ccccc}
\hline \multirow{2}{*}{ Independent Variables } & \multirow{2}{*}{ Symbols } & \multicolumn{3}{c}{ Coded and Actual Levels } \\
\cline { 3 - 5 } & & Low (-1) & Middle (0) & High (+1) \\
\hline Concentration of NaOH (wt.\%) & $\mathrm{X}_{1}$ & 3 & 6 & 9 \\
Soaking duration (hours) & $\mathrm{X}_{2}$ & 3 & 6 & 9 \\
Drying duration (hours) & $\mathrm{X}_{3}$ & 24 & 48 & 72 \\
\hline
\end{tabular}

Table 2 lists the design of the experiment determined by the BBD. This model calculated a total of 17 experimental runs consisting of 12 distinct runs and five replications.

\subsection{Experimental Method}

The bamboo used in this study is Bambusa vulgaris which is generally found in well-drained soil in many tropical regions. Here, the Bambusa vulgaris bamboo was collected from Jeli-Kelantan, on the East Coast of Malaysia and was taken out at approximately $5 \mathrm{~m}$ above the ground. In order to fabricate 
the tensile specimen, the bamboo culm was cut into several smaller pieces using a handsaw and each piece was sliced into four parts as illustrated in Figure 1. Further, these parts were then dried under the sun for a week.

Table 2. Experimental trials derived from Design-Expert Software.

\begin{tabular}{ccccccc}
\hline & \multicolumn{5}{c}{ Independent Variables } \\
\cline { 2 - 7 } RUN & \multicolumn{3}{c}{ Coded Values } & \multicolumn{3}{c}{ Actual Values } \\
\cline { 2 - 7 } & $\mathbf{X}_{\mathbf{1}}$ & $\mathbf{X}_{\mathbf{2}}$ & $\mathbf{X}_{\mathbf{3}}$ & $\mathbf{X}_{\mathbf{1}}$ & $\mathbf{X}_{\mathbf{2}}$ & $\mathbf{X}_{\mathbf{3}}$ \\
\hline 1 & 0 & +1 & -1 & 6 & 9 & 24 \\
2 & 0 & 0 & 0 & 6 & 6 & $48^{*}$ \\
3 & 0 & -1 & -1 & 6 & 3 & 24 \\
4 & 0 & 0 & 0 & 6 & 6 & $48^{*}$ \\
5 & 0 & +1 & +1 & 6 & 9 & 72 \\
6 & +1 & -1 & 0 & 9 & 3 & 48 \\
7 & 0 & 0 & 0 & 6 & 6 & $48^{*}$ \\
8 & 0 & -1 & +1 & 6 & 3 & 72 \\
9 & -1 & +1 & 0 & 3 & 9 & 48 \\
10 & +1 & 0 & +1 & 9 & 6 & 72 \\
11 & 0 & 0 & 0 & 6 & 6 & $48^{*}$ \\
12 & -1 & -1 & 0 & 3 & 3 & 48 \\
13 & -1 & 0 & +1 & 3 & 6 & 72 \\
14 & -1 & 0 & -1 & 3 & 6 & 24 \\
15 & 0 & 0 & 0 & 6 & 6 & $48^{*}$ \\
16 & +1 & +1 & 0 & 9 & 9 & 48 \\
17 & +1 & 0 & -1 & 9 & 6 & 24 \\
\hline \multicolumn{7}{c}{$+{ }^{*}$ replication of middle level =0:0:0). } \\
\end{tabular}

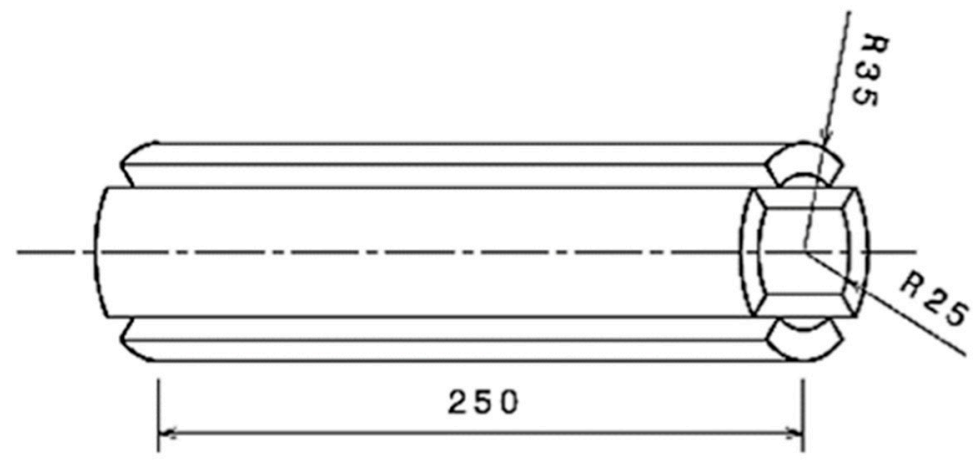

\section{Dimension in $\mathrm{mm}$}

Figure 1. Schematic diagram of the bamboo culm cutting process.

\subsubsection{Alkaline Treatment and Bamboo Fiber-Reinforced Epoxy}

Initially, the bamboo culm was sliced using a sharp straight-edged knife, giving a longitudinal thin bamboo as shown in Figure 2a. To eliminate any dirt and surface impurities, the sliced bamboo was washed with deionized water, before being soaked in 3, 6, and $9 \mathrm{wt} . \%$ [17] concentration $\mathrm{NaOH}$ (Figure $2 \mathrm{~b}$ ). These bamboos were again washed using distilled water for 3, 6 and $9 \mathrm{~h} \mathrm{[18]} \mathrm{according}$ to the conditions suggested by the Box-Behnken design, and then left to dry for 24,48 , and $72 \mathrm{~h}$ in a circulating oven at $80^{\circ} \mathrm{C}$ [19]. The dried bamboo, as shown in Figure 2c, was then ground down using a Cheso Model N3 crusher machine (Figure 2d). In order to maintain the fiber length, a multi stage sieve fixed to a rotational shaker model BS410/1986 (Endecots Ltd., London, England) (Figure 2e) was used. Figure $2 \mathrm{f}$ shows the short fiber was obtained from this shaker when operated at $275 \mathrm{rpm}$ for 45 min. Then, the epoxy-resin (EpoxAmite ${ }^{\mathrm{TM}}$, Smooth-On Inc., Pennsylvania, PA, USA) matrix with fibers was gradually mixed with fiber at 29.86 (wt.\%) of fiber loading [20]. Figure $2 \mathrm{~g}$ illustrates the dumbbell-shaped specimens adhered to the ASTM D638 standard [21] that were cured overnight 
using a rigid steel mold. These flat specimens were typically dimensioned as $165 \mathrm{~mm}$ (overall length), $13 \mathrm{~mm}$ (width) $\times 57 \mathrm{~mm}$ (gauge length) $\times 3 \mathrm{~mm}$ (thickness) with an average weight of $9.50 \pm 0.55 \mathrm{~g}$.

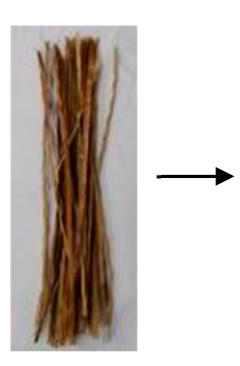

(a)

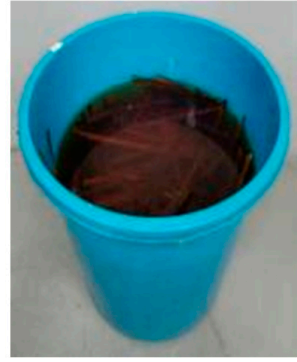

(b)
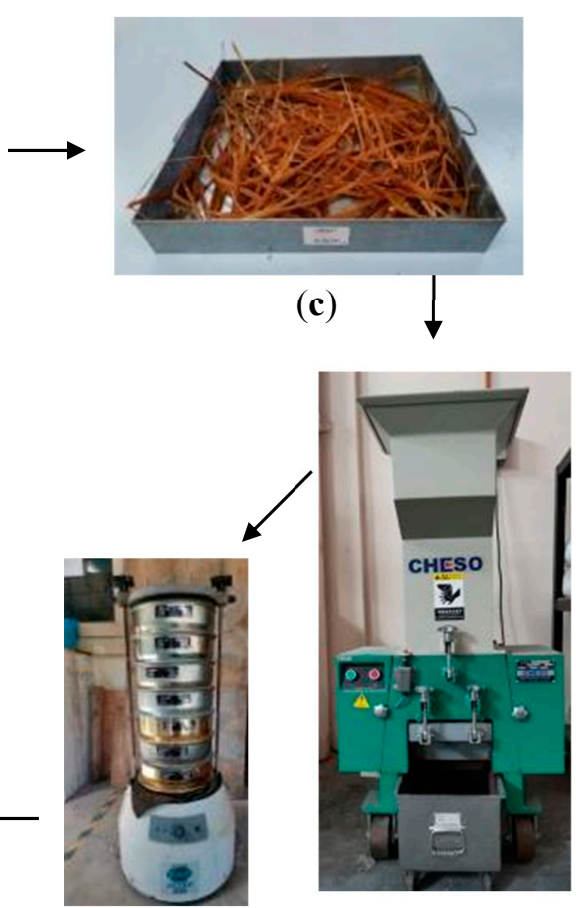

(e) (d)

(g)

(f)

Figure 2. Typical chemical treatment process and dumbbell-shaped bamboo epoxy composite fabrication where (a) raw bamboo fibers, (b) soaking fibers into $\mathrm{NaOH}$ solution, (c) dried bamboo fibers, (d) grounding down fibers, (e) sieved the fibers, (f) obtaining the desired short bamboo fibers and $(\mathrm{g})$ tensile-molded specimens.

\subsubsection{Tensile Test of Bamboo Fiber-Reinforced Epoxy}

Tensile testing was carried out to investigate the effect of alkaline treatment on the tensile properties of the bamboo-reinforced epoxy composite. A specimen was mounted on a Shimadzu universal testing machine (Shimadzu Corporation, Kyoto, Japan) and the test was conducted at a crosshead displacement rate of $1 \mathrm{~mm} / \mathrm{min}$ using a $10 \mathrm{kN}$ load cell. The load displacement relationship was recorded and the test was stopped upon specimen fracture. The mechanical properties including tensile stress, $\sigma$ (MPA), strain-at-break, $\varepsilon(\%)$, and Young's modulus $E$ (GPa) of the composite, were deduced from the stress-strain curves. At least five specimens were tested for each condition and the average value subsequently recorded.

\subsubsection{Compression Test of Bamboo Fiber-Reinforced Epoxy Structure}

The compression test was conducted to investigate the compressive behavior and energy absorption characteristics of triangular and square core structures made of bamboo composites. Initially, bamboo fibers were gradually mixed with epoxy-resin paste and placing in picture frame mold. In order to avoid the composite stacking to the mold, thin layers of Teflon sheet were used as shown in Figure 3a. Further, the panel was then heated to $70{ }^{\circ} \mathrm{C}$ for one hour under a pressure of 1 bar using a hot press machine before leaving them to cure. Figure $3 b, c$ shows the construction of triangular and square core structures, respectively. The design of these structures were adopted from Zuhri et al. [22]. The core structures were prepared by cutting the composite into strip sized $70 \mathrm{~mm} \times 20 \mathrm{~mm}$ with a series of 
$10 \mathrm{~mm}$ depth slots at a distance of $20 \mathrm{~mm}$ apart on each strip using a laser cutter. These triangular and square cores were assembled using a slotting technique giving a total height of $20 \mathrm{~mm}$.

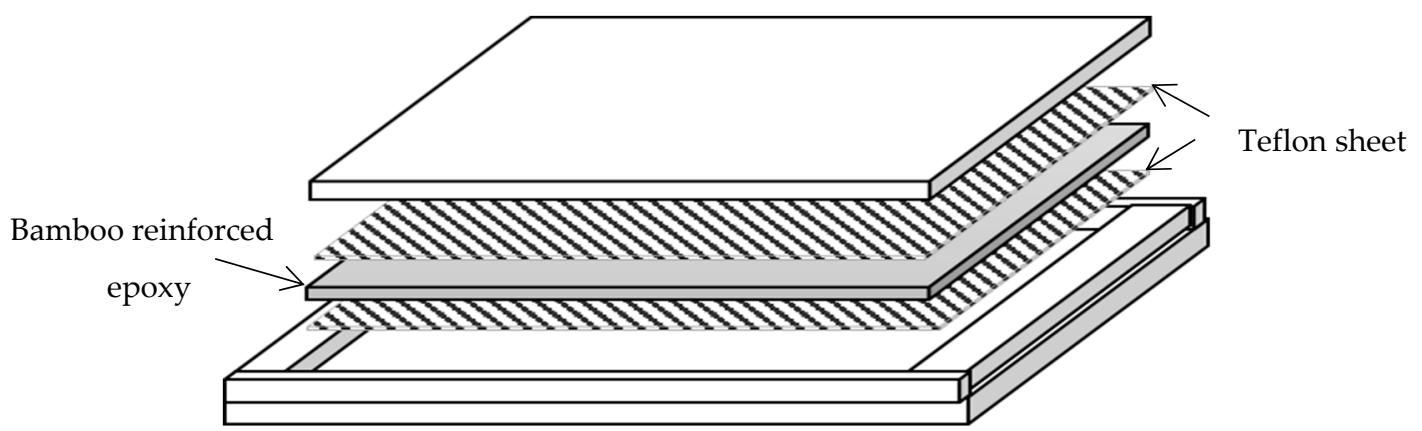

(a)

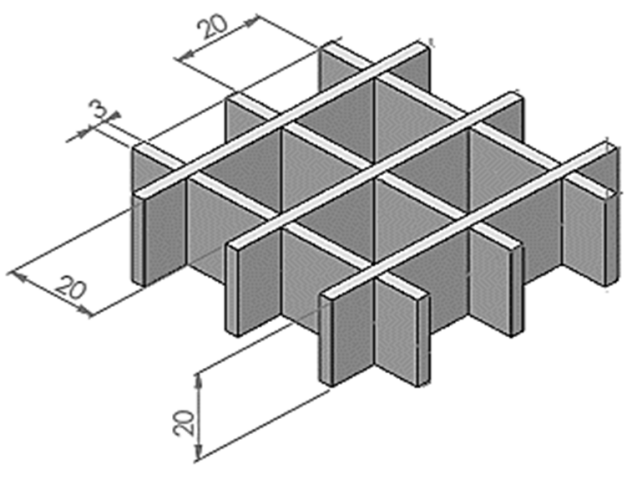

(b)

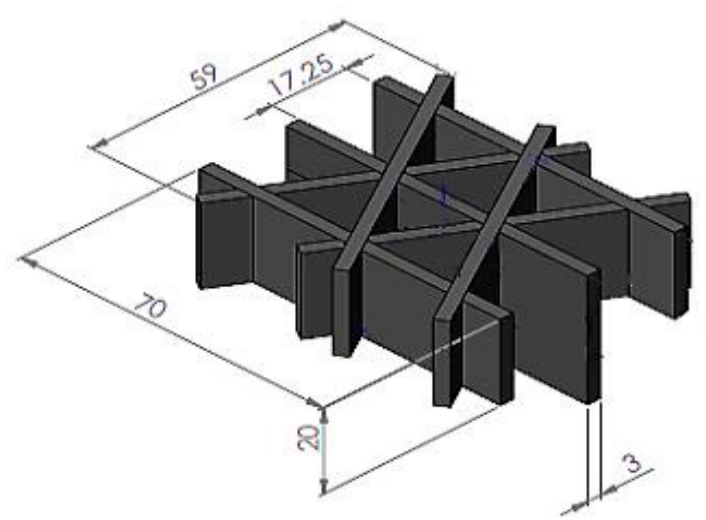

dimension in $\mathrm{mm}$

(c)

Figure 3. Schematic of (a) the bamboo-reinforced epoxy panel, with the (b) the square and (c) the triangular core structures.

The compression tests for both core structures were carried out using Shimadzu universal testing machine according to ASTM C365 [23]. The honeycomb core structure was then placed between a rigid platen and the base and loaded at a crosshead displacement rate of $1 \mathrm{~mm} / \mathrm{min}$. The tests were stopped when the specimens were totally crushed. The test was repeated three times for each condition.

\section{Results and Discussion}

\subsection{Tensile Properties of Bamboo Reinforced Epoxy Composites}

The tensile properties of bamboo composite with different treatment conditions are tabulated in Table 3. The treated bamboo at the median $\mathrm{NaOH}$ concentration, the longest soaking time and dry duration shows the highest tensile strength value (labelled as specimen run 7), whereas the lowest tensile strength was specimen run 2. By comparing both results, the bamboo composite treated with $6 \mathrm{wt} . \% \mathrm{NaOH}$, with $3 \mathrm{~h}$ soaking and $72 \mathrm{~h}$ drying time, exhibited the highest tensile strength, which is $28 \%$ higher than the $9 \mathrm{wt} . \% \mathrm{NaOH}-6 \mathrm{~h}$ soaking $-24 \mathrm{~h}$ drying time sample. This result shows that $6 \mathrm{wt} . \% \mathrm{NaOH}$, with $3 \mathrm{~h}$ soaking and $72 \mathrm{~h}$ drying time, could increase the tensile strength significantly compared to the other treatment conditions. It can be suggested that a bamboo-reinforced epoxy composite treated under these conditions has had the impurities effectively removed from the bamboo surface and so offers a better fiber-matrix adhesion along with the interfacial loading transfer between the fiber and the matrix [18]. The results also show that there is an increase in tensile strength value for the longer drying time of the composite. This reason for this longer drying time is to ensure the removal of the $\mathrm{NaOH}$ residue through the fiber surface [24]. El Sheikh et al. [25] mentioned that 
residual $\mathrm{NaOH}$ has a negative effect on the fiber-matrix adhesion, which explains the decreasing value of the mechanical properties of the structure. In addition, the tensile strength of the bamboo composites steadily increased with increased of the drying time. Zikri et al. [26] reported that the tensile strength of the fiber-epoxy composites significantly decreased by more than $50 \%$ under wet conditions. Here, under high moisture content, the water molecules within the composites weaken the intermolecular hydrogen bonding between the cellulose molecules of the fiber and the water molecules [27], hence the interfacial adhesion between the fiber and the matrix was significantly reduced.

Table 3. Alkaline treatment conditions and test results for bamboo reinforced epoxy composites.

\begin{tabular}{|c|c|c|c|c|}
\hline No. & Conditions & Tensile Strength, $\sigma(\mathrm{MPa})$ & Strain at Break, $\varepsilon(\%)$ & Young's Modulus E (GPa) \\
\hline 0 & Untreated bamboo fiber & $138.88 \pm 1.23$ & $2.70 \pm 0.45$ & $4.96 \pm 0.23$ \\
\hline 1 & 3 wt. $\% \mathrm{NaOH}+3$ h soak +48 h dry & $276.98 \pm 1.45$ & $7.68 \pm 3.30$ & $3.05 \pm 0.84$ \\
\hline 2 & 3 wt. $\% \mathrm{NaOH}+6$ h soak +24 h dry & $253.09 \pm 6.23$ & $7.25 \pm 1.33$ & $3.66 \pm 0.92$ \\
\hline 3 & 3 wt. $\% \mathrm{NaOH}+6$ h soak +72 h dry & $312.29 \pm 2.45$ & $8.49 \pm 2.47$ & $3.14 \pm 0.62$ \\
\hline 4 & 3 wt. $\% \mathrm{NaOH}+9$ h soak +48 h dry & $268.82 \pm 3.35$ & $6.67 \pm 1.78$ & $3.74 \pm 0.56$ \\
\hline 5 & 6 wt. $\% \mathrm{NaOH}+3$ h soak +24 h dry & $263.74 \pm 2.25$ & $5.90 \pm 2.13$ & $3.78 \pm 0.72$ \\
\hline 6 & 6 wt. $\% \mathrm{NaOH}+3$ h soak +72 h dry & $339.27 \pm 3.36$ & $8.33 \pm 2.73$ & $3.70 \pm 0.31$ \\
\hline 7 & 6 wt. $\% \mathrm{NaOH}+6$ h soak +48 h dry & $296.19 \pm 4.26$ & $7.59 \pm 1.55$ & $3.25 \pm 0.69$ \\
\hline 8 & 6 wt. $\% \mathrm{NaOH}+9$ h soak +24 h dry & $301.52 \pm 7.45$ & $8.45 \pm 3.34$ & $3.00 \pm 0.46$ \\
\hline 9 & 6 wt. $\% \mathrm{NaOH}+9$ h soak +72 h dry & $296.19 \pm 4.26$ & $7.59 \pm 1.55$ & $3.25 \pm 0.69$ \\
\hline 10 & 9 wt. $\% \mathrm{NaOH}+3$ h soak +48 h dry & $260.13 \pm 1.73$ & $5.68 \pm 2.05$ & $4.50 \pm 0.13$ \\
\hline 11 & 9 wt. $\% \mathrm{NaOH}+6$ h soak +24 h dry & $226.85 \pm 0.83$ & $7.36 \pm 0.86$ & $3.43 \pm 0.55$ \\
\hline 12 & 9 wt. $\% \mathrm{NaOH}+6$ h soak +72 h dry & $304.92 \pm 2.45$ & $8.49 \pm 2.47$ & $3.14 \pm 0.62$ \\
\hline 13 & 9 wt. $\% \mathrm{NaOH}+9$ h soak +48 h dry & $242.25 \pm 2.24$ & $6.17 \pm 1.06$ & $4.39 \pm 0.37$ \\
\hline
\end{tabular}

As shown in Table 3, the tensile strength significantly decreased with increasing to $9 \mathrm{wt} . \%$ of $\mathrm{NaOH}$ concentration except at higher soaking and drying time. This reduction in mechanical behaviour was also reported by Misra et al. [28] when the sisal fibers were treated with $10 \mathrm{wt} . \% \mathrm{NaOH}$ concentration. Moreover, Oushabi et al. [29] stated that, at high concentrations of $\mathrm{NaOH}$, the fiber pull-out energy that correlated with the fracture energy decreases due to irregularities in the contact surfaces between the fiber and the matrix. This massive delignification process tends to reduce the diameter and excessively damage the fiber leading to poor fiber-matrix adhesion [29]. There are inconsistent trends for strain-at-break and Young's modulus for all treatment conditions, but the differences between them are quite insignificant and can be considered negligible. However, the improvement up to $214.4 \%$ detected on the strain at break for alkaline treated bamboo compared to untreated one. The alkaline treatment made the composites more elastic than brittle untreated bamboo/epoxy composites.

Figure 4 shows the stress-strain curves for bamboo reinforced epoxy composites treated with $3 \mathrm{wt} . \%$, concentrations at different soaking and drying time. The bamboo treated with $3 \mathrm{wt} . \% \mathrm{NaOH}$, $6 \mathrm{~h}$ soaking and $72 \mathrm{~h}$ drying, yields a higher tensile strength with a lower deformation compared to the bamboo fibers under treatment conditions of $3 \mathrm{~h}$ soaking with $48 \mathrm{~h}$ drying time, $6 \mathrm{~h}$ soaking with $24 \mathrm{~h}$ drying time, and $9 \mathrm{~h}$ soaking with $48 \mathrm{~h}$ drying time. The enhancement of $23.4 \%$ is revealed at median soaking time and higher of the drying time that compare with other conditions at same $3 \mathrm{wt} . \%$ $\mathrm{NaOH}$ concentration. Fracture of the specimen may be due to the formation of peaks and valleys that that concentrate the load at a particular point on the composites as a result of higher mechanical properties. Meanwhile, the relationship between soaking and drying time is discussed in details at BBD discussion section. Manalo et al. [11] conducted a tensile test of treated bamboo fiber polyester composites. They indicated the average tensile stress is $19 \mathrm{MPa}$ for those specimens, which is 15 fold lower than reported here. Besides the different type of polymer matrix and matrix adhesion between the fiber-matrix reinforced composite, they also suggested that the tensile behavior of bamboo fibers is dominated by the orientation of the fiber.

\subsection{Box Behnken Design (BBD) Analysis of Treated Bamboo Reinforced Epoxy Composites}

By applying the analysis of variance, the quadratic model for tensile strength of the treated bamboo reinforced epoxy composite is expressed in Equation (2). The comparison between calculated 
tensile strength and the experimental findings for the treated bamboo reinforced epoxy composites are summarized in Table 4.

$$
\begin{aligned}
& \text { Tensile strength }=117.115+30.39\left(X_{1}\right)+16.10\left(X_{2}\right)+1.14\left(X_{3}\right)-2.92\left(X_{1}{ }^{2}\right)-1.16\left(X_{2}{ }^{2}\right)+0.003\left(X_{3}{ }^{2}\right) \\
& -0.27\left(X_{1} X_{2}\right)+0.066\left(X_{1} X_{3}\right)-0.073\left(X_{2} X_{3}\right)
\end{aligned}
$$

where $X_{1}, X_{2}$, and $X_{3}$ are corresponding coded variables of $\mathrm{NaOH}$ concentration $\left(X_{1}\right)$, soaking period $\left(X_{2}\right)$, and drying time $\left(X_{3}\right)$.

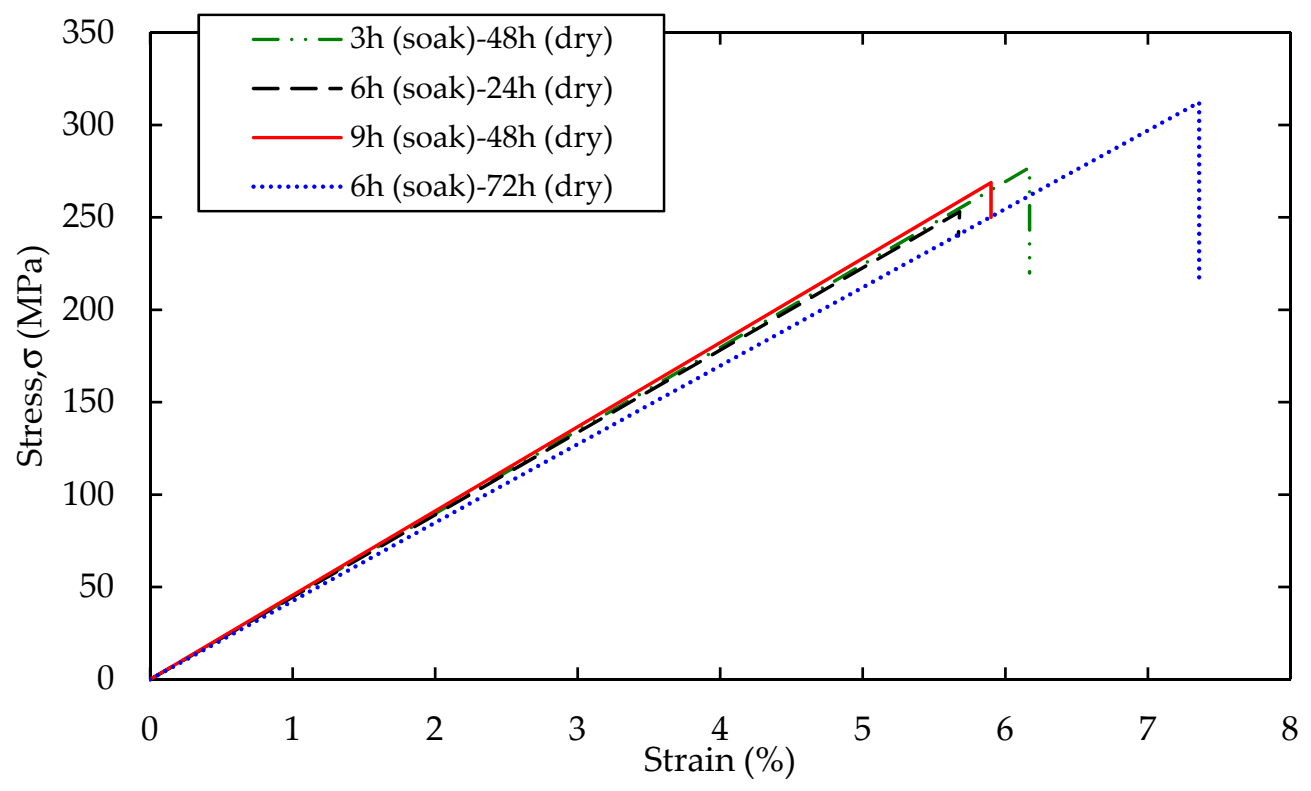

Figure 4. Typical stress-strain curves bamboo reinforced epoxy composites treated with of 3 wt.\%, $\mathrm{NaOH}$ concentration.

\begin{tabular}{|c|c|c|c|c|c|c|c|c|c|c|}
\hline \multirow{3}{*}{ Run } & \multicolumn{6}{|c|}{ Independent Variables } & \multicolumn{3}{|c|}{ Tensile Strength (MPa) } & \multirow{3}{*}{ Error (\%) } \\
\hline & \multicolumn{3}{|c|}{ Coded Values } & \multicolumn{3}{|c|}{ Actual Values } & \multirow{2}{*}{ Experimental } & \multirow{2}{*}{ Predicted } & \multirow{2}{*}{ Residual } & \\
\hline & $X_{1}$ & $X_{2}$ & $\mathrm{X}_{3}$ & $X_{1}$ & $X_{2}$ & $X_{3}$ & & & & \\
\hline 1 & -1 & 0 & +1 & 3 & 6 & 72 & 312.29 & 312.61 & -0.325 & -0.102 \\
\hline 2 & +1 & 0 & -1 & 9 & 6 & 24 & 226.85 & 226.53 & 0.325 & 0.141 \\
\hline 3 & 0 & -1 & -1 & 6 & 3 & 24 & 263.74 & 260.42 & 3.32 & 1.259 \\
\hline 4 & 0 & 0 & 0 & 6 & 6 & 48 & 298.89 & 298.86 & 0.03 & 0.010 \\
\hline 5 & -1 & -1 & 0 & 3 & 3 & 48 & 276.98 & 278.17 & -1.19 & -0.430 \\
\hline 6 & 0 & +1 & +1 & 6 & 9 & 72 & 306.08 & 309.40 & -3.32 & -1.085 \\
\hline 7 & 0 & -1 & +1 & 6 & 3 & 72 & 339.27 & 337.75 & 1.52 & 0.448 \\
\hline 8 & +1 & -1 & 0 & 9 & 3 & 48 & 260.13 & 263.77 & -3.64 & -1.399 \\
\hline 9 & 0 & 0 & 0 & 6 & 6 & 48 & 301.52 & 298.86 & 2.66 & 0.882 \\
\hline 10 & 0 & 0 & -1 & 6 & 9 & 24 & 251.55 & 253.07 & -1.52 & -0.604 \\
\hline 11 & 0 & 0 & 0 & 6 & 6 & 48 & 297.25 & 298.86 & -1.61 & -0.542 \\
\hline 12 & +1 & 0 & +1 & 9 & 6 & 72 & 304.92 & 302.79 & 2.13 & 0.699 \\
\hline 13 & -1 & 0 & -1 & 3 & 6 & 24 & 253.09 & 255.22 & -2.13 & -0.842 \\
\hline 14 & 0 & 0 & 0 & 6 & 6 & 48 & 300.45 & 298.86 & 1.59 & 0.529 \\
\hline 15 & 0 & 0 & 0 & 6 & 6 & 48 & 296.19 & 298.86 & -2.67 & -0.901 \\
\hline 16 & +1 & +1 & 0 & 9 & 9 & 48 & 242.25 & 241.06 & 1.19 & 0.491 \\
\hline 17 & -1 & +1 & 0 & 3 & 9 & 48 & 268.82 & 265.18 & 3.64 & 1.354 \\
\hline
\end{tabular}

Table 4. Box-Behnken Design (BBD) analysis with experimental and predicted values of tensile strength.

A good agreement between actual and predicted data occurs when the residual and the error for the actual tensile strength are less than $2 \%$. Here, this empirical model fitting is used to validate the accuracy of iteration of the three chosen factors using $F$-test and regression coefficient, $R^{2}$. Table 5 tabulates 
the statistical measurements from ANOVA. The measured values the coefficient of determination $\left(R^{2}\right)$ close to 1 indicated the degree of fit. Joglekar et al. [30] reported that a good model fit would yield an $\mathrm{R}^{2}$ value of at least 0.8 . The mean of the response model calculated in this study explains the reaction of the tensile strength with the design factors very well with a value of Adj- $\mathrm{R}^{2}$ value of 0.986 and a Predicted- $\mathrm{R}^{2}$ of 0.924 at a $95 \%$ confident level. The signal-to-ratio was measured by a term called adequate precision. In this study, the ratio was 282.37, which is larger than four, and is thus considered acceptable [31]. Further, the coefficient of variation (C.V.) is less than 10\% [32], which implies that the model is highly reliable.

Table 5. Statistical data from ANOVA for tensile strength.

\begin{tabular}{cc}
\hline Source & Response Value \\
\hline R-Squared $\left(R^{2}\right)$ & 0.994 \\
Adjusted R-Squared & 0.986 \\
Predicted R-Squared & 0.924 \\
Standard Deviation & 3.480 \\
C.V. $\%$ & 1.230 \\
Adequate Precision & 41.71 \\
Mean & 282.37 \\
\hline
\end{tabular}

The analysis of variance data for the tensile strength of the treated bamboo specimens are tabulated in Table 6. This result is used to identify the significance of the model and its parameters following Fisher's F-test and the Student $t$-test. As can be seen from Table 6, larger F-values $\left(\mathrm{F}_{\text {model }}=129.17\right)$ and a smaller $p$-value $(p<0.0001)$ show the high significance of the coefficient level. A $p$-value less than 0.05 indicates that the model is statically significant, while the value larger than 0.10 indicates that the model is not significant [33]. In addition, the correlation coefficient of quadratic terms of $\mathrm{NaOH}$ concentration and drying time are implied to be highly significant. This means that these two factors influence the removal of the hemicellulose content of the fibers. Sari et al. [34] reported that alkaline treatment decreased the moisture content of the fiber, whereas the interstices between the groups of microfibrils would be blocked, thereby reducing water accessibility. In addition, a longer drying time may suggest an additional interfacial bonding strength interaction of the polymer matrix when bamboo is used as the fiber-reinforced in a composite laminate.

Table 6. ANOVA of the quadratic model for alkaline treatment of bamboo.

\begin{tabular}{|c|c|c|c|c|c|}
\hline Source & Sum of Squares & df & Mean Square & F-Value & $p$-Value $($ Prob $>$ F) \\
\hline Model & 14051.43 & 9 & 1561.27 & 129.17 & $<0.0001 *$ \\
\hline $\begin{array}{c}\mathrm{X}_{1^{-}} \\
\text {concentration }\end{array}$ & 741.7 & 1 & 741.7 & 61.36 & 0.0001 \\
\hline $\mathrm{X}_{2}$ - soaking & 637.6 & 1 & 637.6 & 52.75 & 0.0002 \\
\hline$X_{3}$-drying & 8933.17 & 1 & 8933.17 & 739.08 & $<0.0001$ \\
\hline$x_{1}^{2}$ & 23.62 & 1 & 23.62 & 1.95 & 0.2048 \\
\hline$x_{2}^{2}$ & 89.02 & 1 & 89.02 & 7.36 & 0.03 \\
\hline$x_{3}^{2}$ & 110.25 & 1 & 110.25 & 9.12 & 0.0194 \\
\hline$x_{1} X_{2}$ & 2922.08 & 1 & 2922.08 & 241.76 & $<0.0001$ \\
\hline$x_{1} x_{3}$ & 461.67 & 1 & 461.67 & 38.2 & 0.0005 \\
\hline$x_{2} x_{3}$ & 13.21 & 1 & 13.21 & 1.09 & 0.3306 \\
\hline Residual & 84.61 & 7 & 12.09 & & \\
\hline Lack of Fit & 65.28 & 3 & 21.76 & 4.5 & $0.09^{* *}$ \\
\hline Pure Error & 19.33 & 4 & 4.83 & & \\
\hline Cor total & 14136.03 & 16 & & & \\
\hline
\end{tabular}




\subsection{Diagnostic Plots of the Composites}

Figure 5 presents the diagnostic plots of tensile strength for the treated bamboo reinforced epoxy composites. It is evident from these figures that all plots have fulfilled the general statistical assumptions about residuals by displaying a normal data distribution. Figure 5a shows a typical normal probability distribution versus residuals. In the figure where the residuals fall near to the ideal line of regression there is good agreement with the normal distribution which suggests that the model fits the data satisfactorily [35]. On the other hand, Figure $5 \mathrm{~b}$ presents the plot of residuals versus predicted values which show that the data points are randomly scattered across the plot without exceeding the upper and lower limit lines. In general, the studentized residuals should lie between +3 and -3 [36]. In Figure 5b, the optimization value was close to \pm 3 , thereby, along with the pattern of the plot, confirming the accuracy of the proposed model. Figure $5 \mathrm{c}$ presents the predicted and actual values of response which seem to be in a reasonable agreement as the data points are well distributed around the reference line. Therefore, the distribution indicates the high accuracy of the model. To sum up, the proposed model is accurate and fits the data adequately [37].

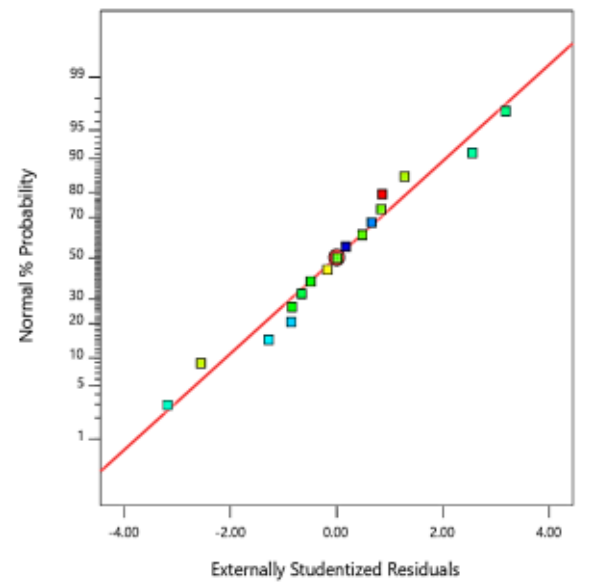

(a)

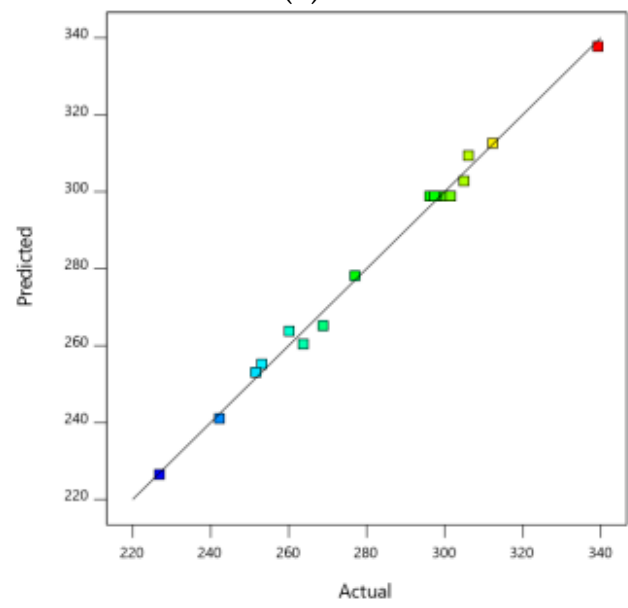

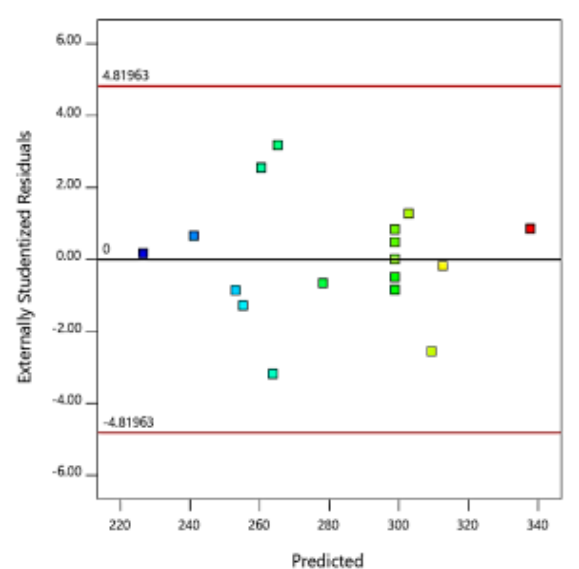

(b)

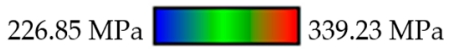

(c)

Figure 5. Diagnostic plots values of (a) normal probability versus residuals, (b) residuals versus predicted and (c) predicted versus actual of tensile strength bamboo reinforced epoxy composites.

Figure 6 shows a perturbation plot which illustrates the effect of treatment conditions on the tensile strength of the treated bamboo reinforced epoxy composites. The plot also describes the changes of response as each variable moves from the centre point of the design space $\left(X_{1}=6.00, X_{2}=6.00\right.$, $\left.X_{3}=48.00\right)$. Here, it shows that the increase in drying time $\left(X_{3}\right)$ has an apparently positive effect on 
the response. In contrast, $\mathrm{NaOH}$ concentration $\left(X_{1}\right)$ and soaking time $\left(X_{2}\right)$ has an adverse effect on the response where the tensile strength decreasing with furthur increasing $\mathrm{NaOH}$ concentration and drying time after it treshold values, implying the decline of alkali effect. In this study, the value the determination indicates the reliability of the model [38].

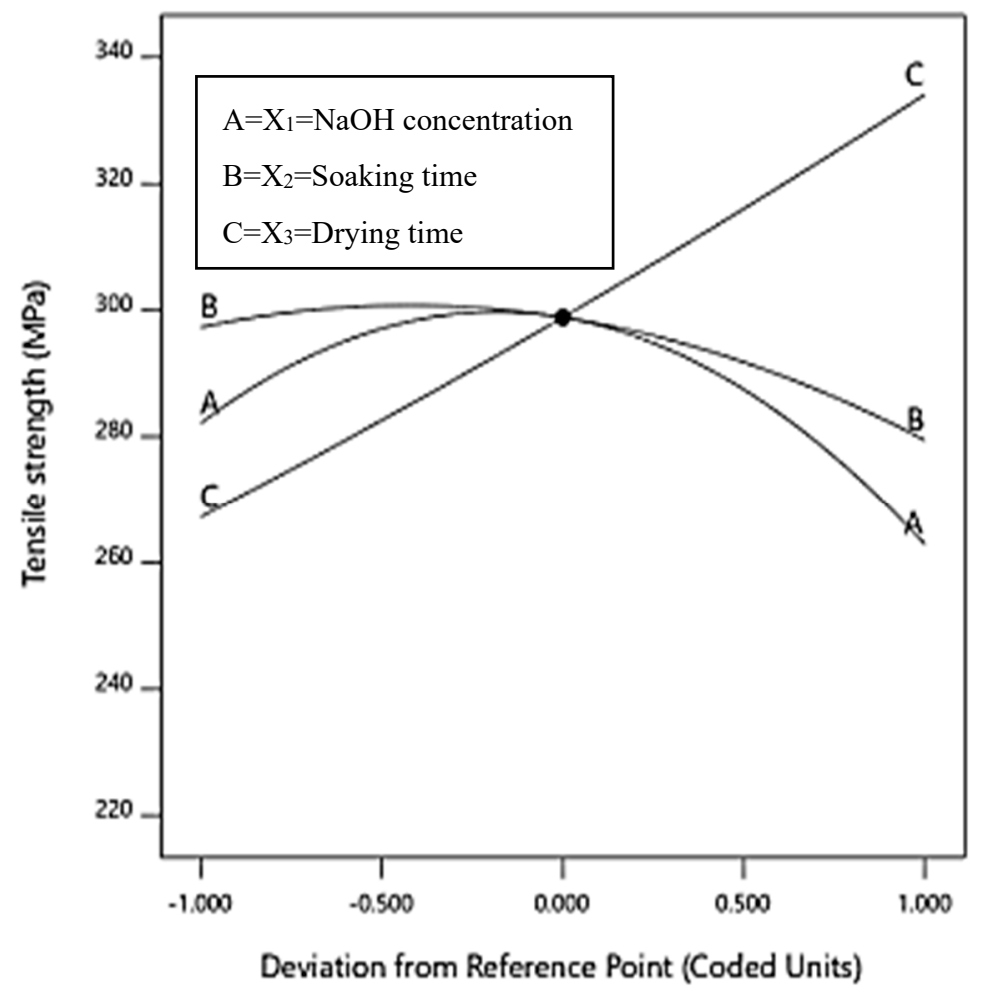

Figure 6. Perturbation plot showing the effect of all the variables on the tensile strength.

\subsection{Response Surface Plots}

Figure 7a presents the response surface and corresponding contour plots for the interaction effect between $\mathrm{NaOH}$ concentration $\left(X_{1}\right)$ and soaking time $\left(X_{2}\right)$ on the tensile strength of bamboo-reinforced epoxy composites at $48 \mathrm{~h}$ drying time $\left(X_{3}\right)$. From the plots, the highest tensile strength of $298.89 \mathrm{MPa}$ was recorded at the median $\mathrm{NaOH}$ concentration $(6 \mathrm{wt} . \%)$ and the soaking time $(6 \mathrm{~h})$. In contrast, the tensile strength of the composites was the lowest $(242.25 \mathrm{MPa})$ when treated with $9 \mathrm{wt} . \%$ concentration of $\mathrm{NaOH}$ for $9 \mathrm{~h}$. This common shape of the 2D and 3D contour plots corresponds to the nature and extent of the relationship between factors [39].

Figure $7 \mathrm{~b}$ presents the response surface and corresponding contour plots for the interaction effect of $\mathrm{NaOH}$ concentration $\left(X_{1}\right)$ and drying time $\left(X_{3}\right)$ on the tensile strength of bamboo-reinforced epoxy composites defaults at $6 \mathrm{~h}$ soaking time $\left(X_{2}\right)$. From the figures, the highest tensile strength of bamboo reinforced epoxy composites was recorded at $312.29 \mathrm{MPa}$ after treatment of $3 \mathrm{wt} . \%$ concentration $\mathrm{NaOH}$ and drying for more than $60 \mathrm{~h}$ at room temperature. However, a drop of tensile strength value to $226.85 \mathrm{MPa}$ is observed at the maximum treatment $\mathrm{NaOH}$ concentration $(9 \mathrm{wt} . \%$ of $\mathrm{NaOH})$ with minimum drying time $(24 \mathrm{~h})$. The deterioration occurring due to the alkali treatment had the greatest influence on the tensile strength as shown in Figure 6. The median range $\mathrm{NaOH}$ concentration delivers higher strength, however, both the lowest and the highest concentration contribute to the deterioration as the highest concentration reveals a more severe drop compared to the lowest one. This response surface is visualized regarding the tendency of each factor generated by the model surface using the second order polynomial (Equation (2)) to influence the tensile strength efficiency. The negligible effects are shown as a circular contour plot, while an elliptical contour plot indicates a prominent interaction [40]. 

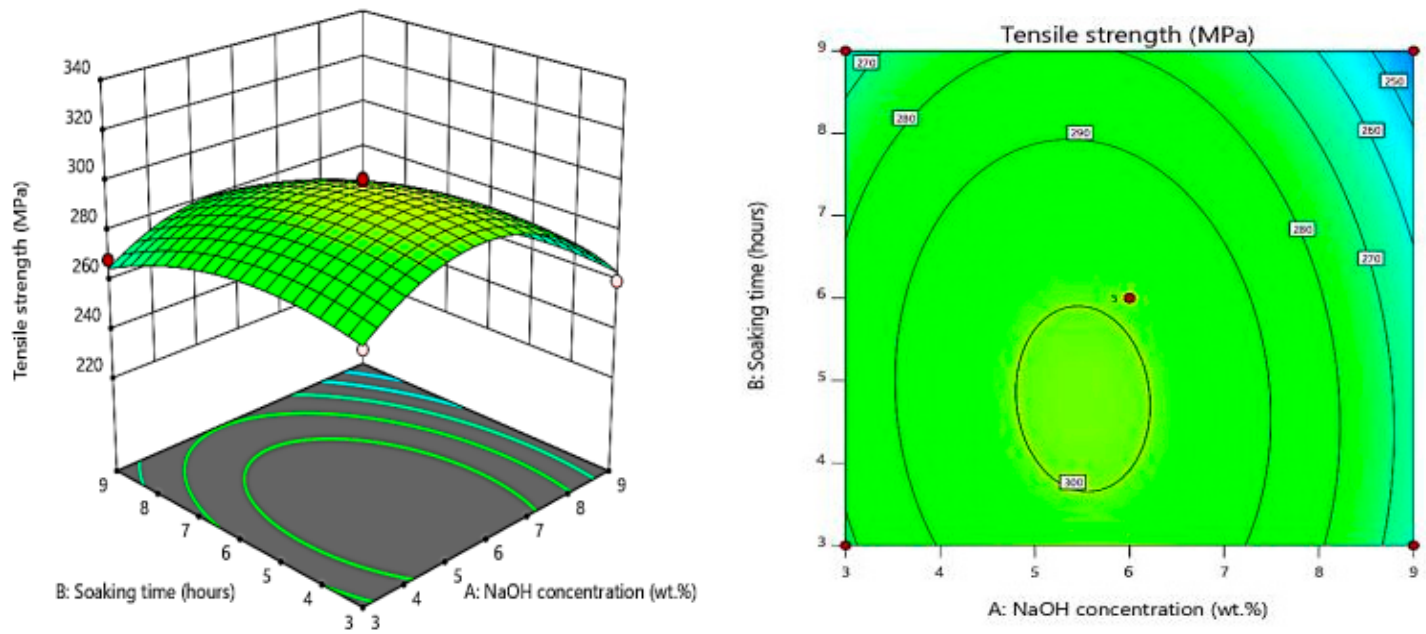

(a)
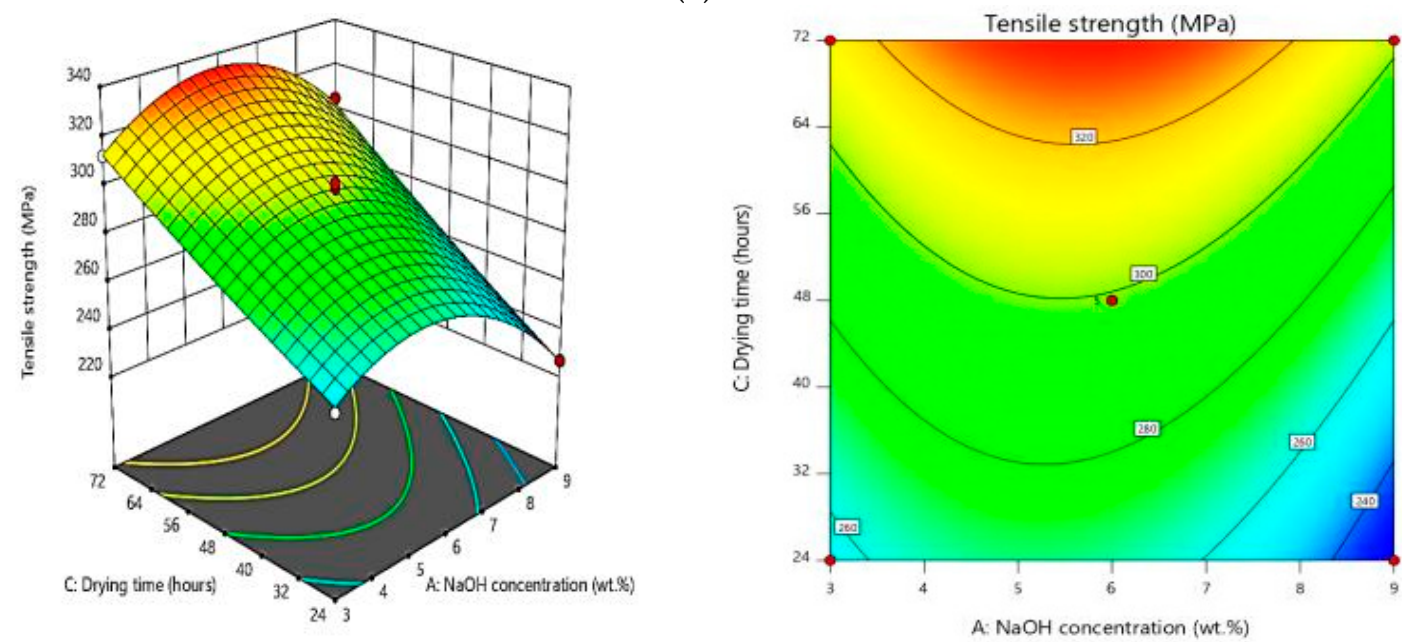

(b)
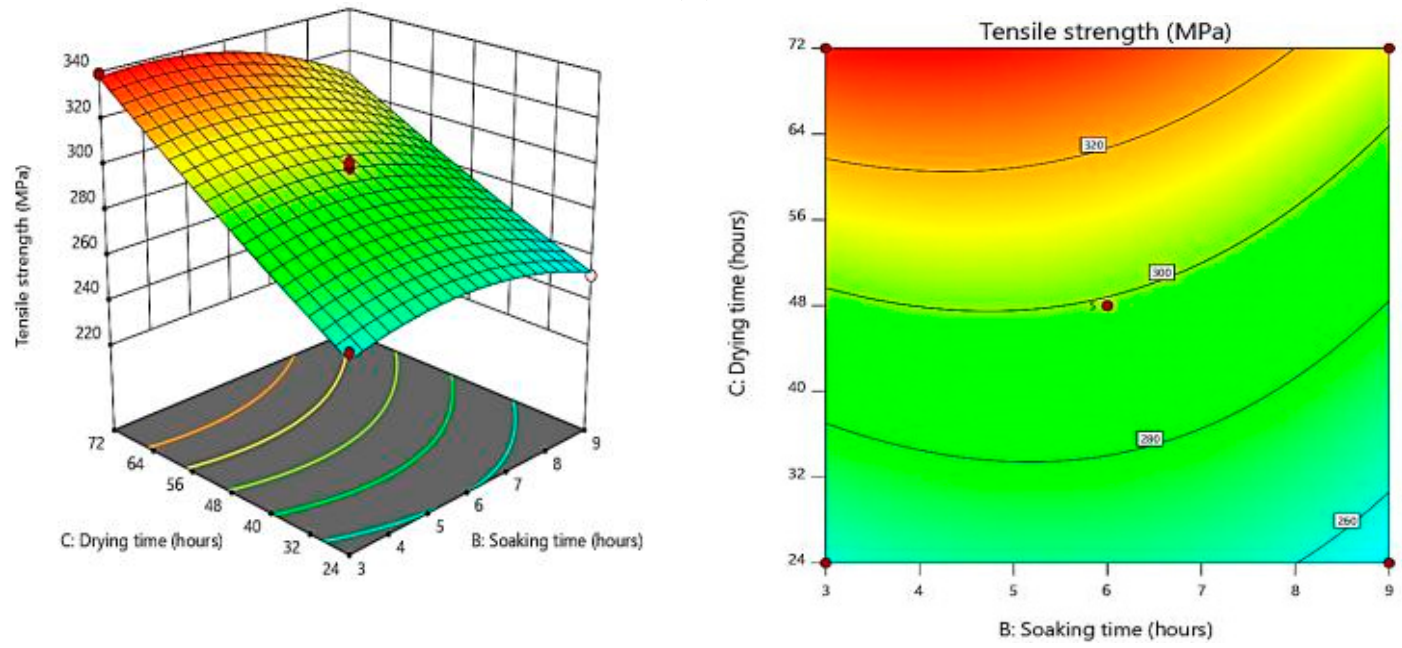

(c)

Figure 7. Typical 3D and 2D plots for the effect of (a) concentration versus soaking time (b) concentration versus drying time and (c) soaking time versus drying time on tensile strengths.

On the other hand, Figure 7c shows the response surface and corresponding contour plots for the interaction effect of soaking time $\left(X_{2}\right)$ and drying time $\left(X_{3}\right)$ on the response in which the bamboo was treated with 6 wt.\% concentration of $\mathrm{NaOH}$. It can be seen that the highest tensile strength of bamboo 
reinforced epoxy composites was achieved at 339.27 MPa under the treatment condition of $6 \mathrm{wt} . \%$ $\mathrm{NaOH}$ with $3 \mathrm{~h}$ soaking and $72 \mathrm{~h}$ drying. The minimum tensile strength of bamboo reinforced epoxy composites when treated with $6 \mathrm{wt} . \%$ concentration of $\mathrm{NaOH}$ was reported to be $251.55 \mathrm{MPa}$ after $9 \mathrm{~h}$ of soaking and drying for $24 \mathrm{~h}$. In order to achieve a maximum tensile strength, Asim et al. [41] proposed that an optimal treatment condition is $6 \mathrm{wt}$. \% concentration $\mathrm{NaOH}$ at $6 \mathrm{~h}$ of soaking time, which decreased the diameter of the pineapple leaf fibers.

\subsection{Condition Optimization and Confirmation Tests}

The tensile strength of bamboo-reinforced epoxy composites increased with the values of both $\mathrm{NaOH}$ concentration and soaking time up to their thresholds, before it then deteriorates as further increases occur. However, the drying time only produces a positive effect that tensile strength increase as the period increases. Following this, the tensile strength increases as the soaking time increased. Based on the analysis, it can be suggested that the highest tensile strength of the treated bamboo reinforced epoxy composite could be achieved up to $339.27 \mathrm{MPa}$ under the treatment condition of $6 \mathrm{wt} . \% \mathrm{NaOH}$ with $3 \mathrm{~h}$ soaking and $72 \mathrm{~h}$ drying time. Meanwhile, the minimum tensile strength was recorded at $226.85 \mathrm{MPa}$ when the bamboo fiber was treated with $9 \mathrm{wt} . \%$ concentration of $\mathrm{NaOH}$ for $6 \mathrm{~h}$ and dried for $24 \mathrm{~h}$.

The optimization function in the Design Expert software was used to obtain the optimal conditions for the bamboo reinforced epoxy composite. The 3D contour plot obtained under optimal conditions is shown in Figure 8. According to the ramp plot shown in Figure 8a, the $\mathrm{NaOH}$ concentration of $5.81 \mathrm{wt} . \%$, a soaking time of $3.99 \mathrm{~h}$, and a drying time of $72 \mathrm{~h}$ are recorded. Here, the corresponding tensile strength is indicated at $338.27 \mathrm{MPa}$. Desirability values close to 1 were selected as the most effective parameters values with respect to the response factor. In this study, the desirability value was equivalent to 0.997 as shown in Figure $8 \mathrm{~b}$. The typical tensile strength cube for optimization is shown in Figure $8 \mathrm{c}$. The good agreement between the experimental and predicted results verifies the validity of the model. To confirm the validity of the predicted optimal response, three additional experiments were carried out. For the three repeated experiment, the average tensile strength among was more than $85 \%$. Wang et al. [42] examined the elementary aspect of the effect of alkali treatment on the cellulose of in bamboo fiber during the hydration reaction. This mercerization transition phenomenon leads to fibrillation by removing waxing materials. It also reduces the fiber diameter and increases its aspect ratio. In addition, Qian et al. [43] claimed that optimal alkali treatment increased the specific area of bamboo fiber, which could increase the possibility of matrix penetration into the fiber surface. These results are acceptable, indicating that a BBD is a very effective tool for optimizing individual factors in a new process.

\subsection{Compression Properties of Bamboo Reinforced Epoxy Structures}

The compression tests of selected alkaline treatment conditions on triangular and square core structures made of bamboo reinforced epoxy composite were examined. Figure 9 shows the force-displacement traces of untreated and treated sample of both triangular and square core structures of bamboo reinforced epoxy composites. Interestingly, treated core structures offered outstanding performance compared to the untreated systems. The composite structure treated using optimum conditions, i.e., $5.81 \mathrm{wt} . \%$, a soaking time of $3.99 \mathrm{~h}$, and a drying time of $72 \mathrm{~h}$, exhibited the highest compressive strength. As can be seen from the force-displacement traces, the peak for this treatment condition was greater compared to untreated structures. This implied that the treatment was a good surface treatment for enhancing the interface bonding between bamboo fiber and the epoxy matrix [44], thus enabling the core structures to withstand higher the higher compressive forces exerted upon them. 

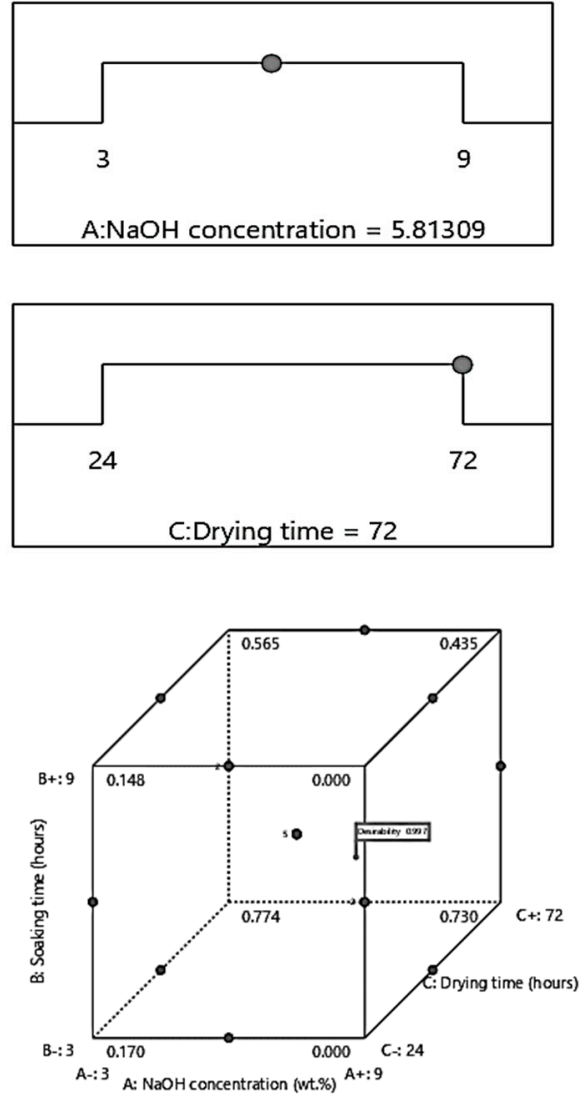

(b)
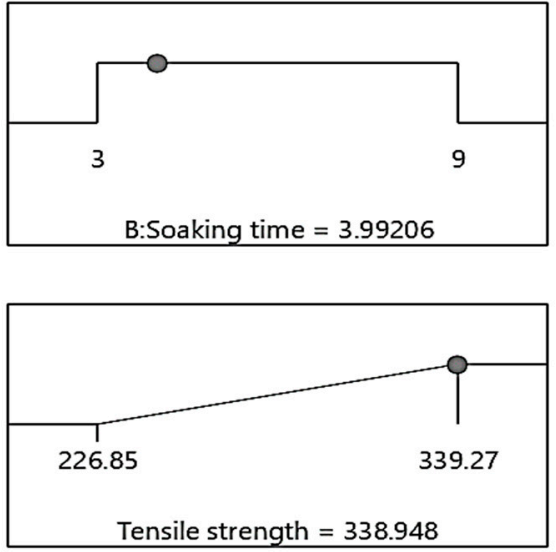

(a)

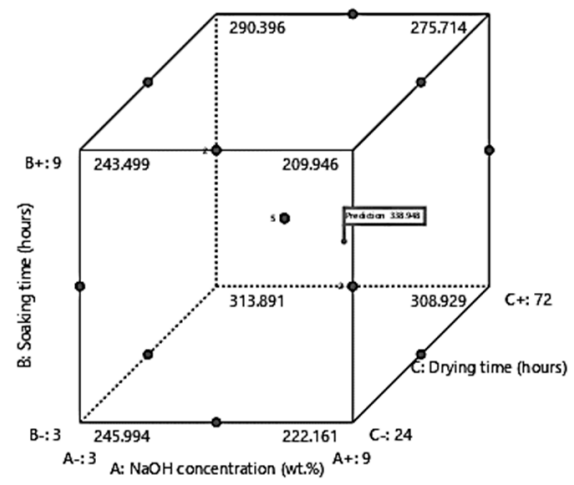

(c)

Figure 8. Typical (a) ramp, (b) desirability cube and (c) tensile strength cube represent the effect of $\mathrm{NaOH}$ concentration, soaking time and drying time under optimal conditions.

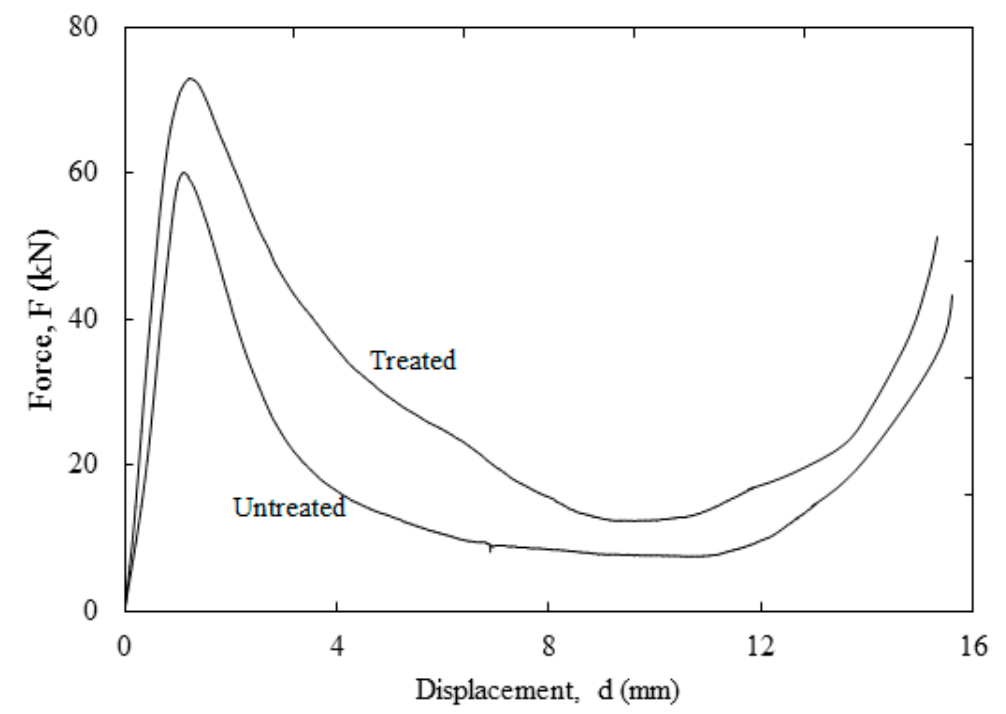

Figure 9. Typical force-displacement traces for untreated and treated square structures.

In Figure 10, four typical phases could be observed with the elastic deformation region in the initial region. Here, the compressive load for square and triangular core structures steadily increases with displacement. Upon reaching the maximum load, the loading force exhibited by the triangular structure continues to increase slightly higher than square core. This could be explained by the differences in relative density of both cores where a core with higher relative density requires an immense amount of 
compressive load to deform. In addition, the relative density of the triangular structure was almost $20 \%$ of its square counterpart, thus explaining the higher peak loading experienced by the triangular core. Also, the prior cracks in the structures started to become visible as the stress was concentrated at this condition. In addition, the traces gradually decrease as the structures become unable to withstand the applied force. Thus, both cores started to fail. As the structures start to lose their rigid stability, the compressive load fell to almost half of the maximum compressive strength. Then, they reached a steady stage where the cell walls of the structures started to crack at their cell wall over almost half of the structure. The rupture of bamboo fibers in the composite was also noticeable. In addition, both structures show a failure mode of cracking at the cell wall thickness with a micro-buckling observed at the triangular core structure. The traces show that, after reaching the densification phase, both structures were utterly crushed, and the compressive load increased. Here, the overall compressive properties of triangular core structures outperformed the square counterparts for both untreated and treated samples. One factor that influenced the results is the core topology. According to Yamashita and Gotoh [45], a higher number of cells provide more support in resisting the compressive load. Their suggestion is in agreement with Hazizan and Cantwell [46], who reported that the same factor greatly influenced the portioning of energy. Moreover, the core with a smaller cell size is more preferable in the composite industry as this type of core is capable of preventing its structure from buckling under compressive load longer than a core structure with large cell size. Larger cells, unfortunately, tend to collapse inwards as the bonding between the fiber and matrix becomes weakened.

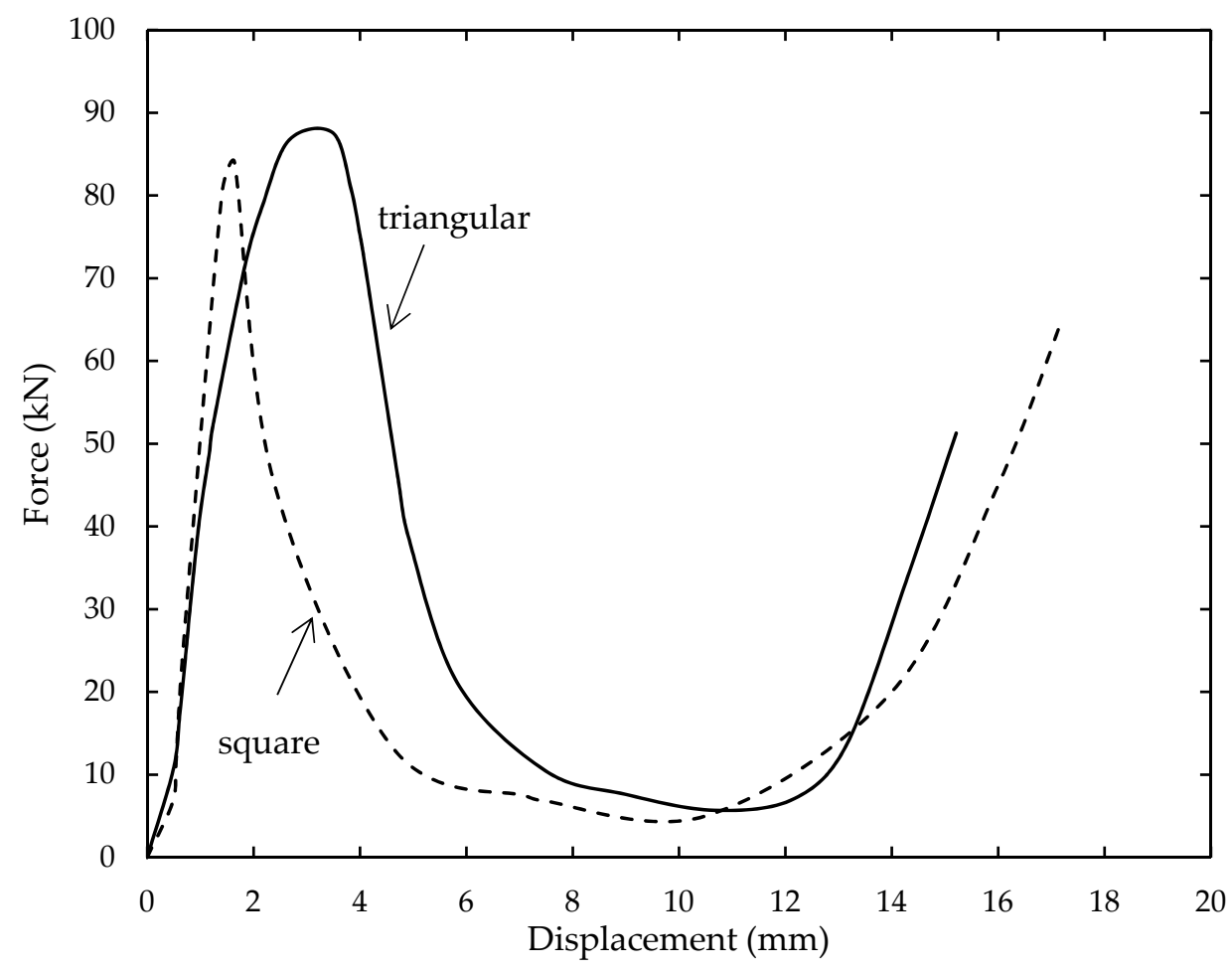

Figure 10. Typical force-displacement traces of square and triangular core structures.

Figure 11 shows the energy-absorbing characteristics for both square and triangular core structures. The specific energy absorption of the square and triangular composite core structures was calculated from the area under curve of force-displacement curves over the mass of the structures. The highest specific energy was recorded for the triangular core structure treated with the highest optimal $\mathrm{NaOH}$ concentration. On the other hand, the square structure with similar treatment conditions exhibited approximately $7 \%$ less specific energy than the triangular structure as the lower cell size and smaller number of cells render the square core incapable of withstanding greater compressive load compared to the triangular core. Furthermore, a triangular bamboo structure treated under optimal condition 
is highly superior than those treated composite by over $12 \%$. Zuhri et al. [22] suggested that the energy-absorbing characteristics of the core structure can be affected by the poorer mechanical properties of the composite. In their study, they conducted compression tests on square and triangular flax/polypropylene and flax/PLA sandwich structures.

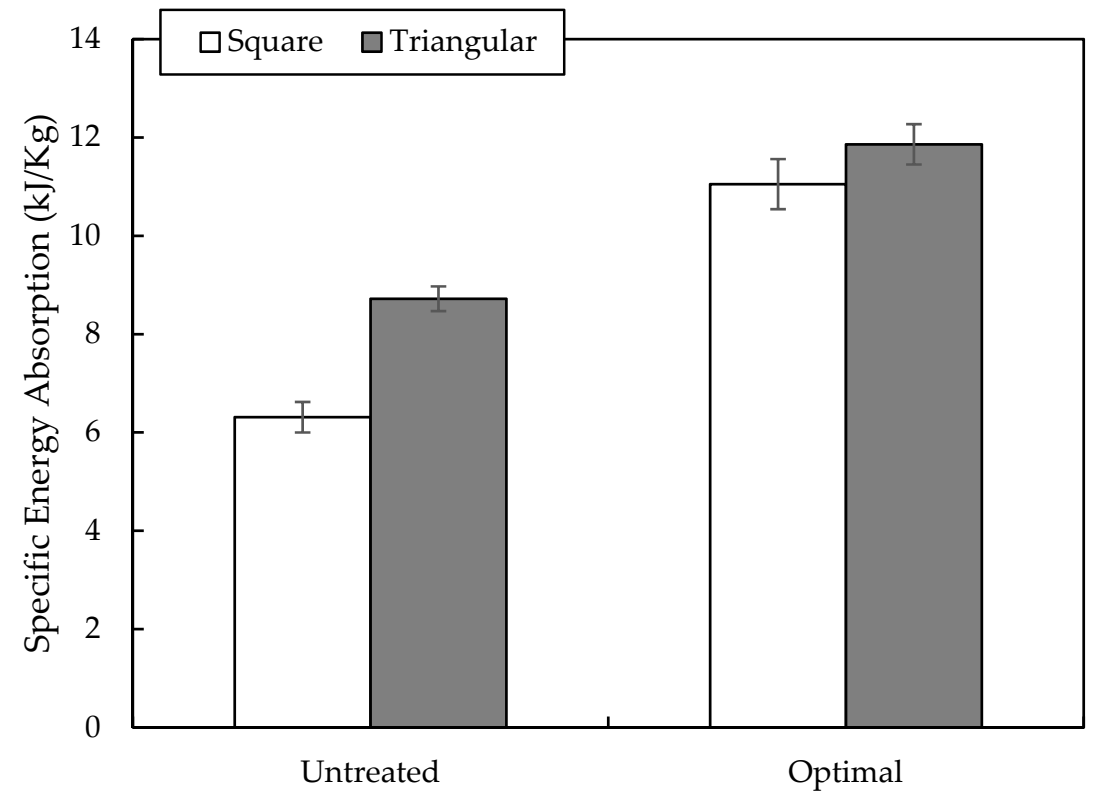

Figure 11. Energy absorption characteristics of bamboo reinforced epoxy square and triangular sandwich core structures.

\section{Conclusions}

A series of mechanical tests were carried out on bamboo fiber subjected to a range of treatment conditions. The alkaline treatment conditions comprised $\mathrm{NaOH}$ concentration, soaking time, and drying time and were optimized using a Box-Behnken design. Then, BBD data were analyzed using ANOVA to produce the statistical results. It was found that the treatment variables were significantly involved in the mechanical properties of the bamboo reinforced epoxy composite. The optimum mercerization condition for bamboo is a NaOH concentration of $5.81 \mathrm{wt} . \%$, a soaking time of $3.99 \mathrm{~h}$, and a drying time of $72 \mathrm{~h}$ with a tensile strength of $338.95 \mathrm{MPa}$ being recorded. The optimum alkaline treatment once again had a great effect on the structures where all the treated square and triangular cores outperformed the untreated fibers under compressive stress. The triangular structure based on treated bamboo reinforced epoxy composites shows an outstanding performance compared to its treated square counterpart in terms of compressive and specific strength. This is due to the high number of small cells. Again, the triangular core structure based on treated bamboo reinforced epoxy composite showed its superiority by absorbing $7 \%$ more energy compared to the treated square core structures.

Author Contributions: M.Z.H.-Project administrative; S.A.R.-Writing-original draft; S.M.S.-Supervision, Z.A.R.-Formal analysis; A.F.M.N.-Writing—review \& editing; M.Y.M.D.-Funding acquisition; R.D.-Resources; M.Z.M.Y.-Investigation. All authors have read and agreed to the published version of the manuscript.

Funding: This research was funded by Universiti Teknologi Malaysia with “Geran Universiti Penyelidik' (GUP) Tier 2 Scheme Q.K.130000.2656.15J85, Tier 2 Scheme Q.K.130000.2656.17J66, UTMFR Scheme Q.K.130000.2656.21H13 and UTMER Scheme Q.K.130000.2656.18J24 financial support provided throughout the course of this research project. The authors would like to thank the Ministry of Higher Education Malaysia and Universiti Putra Malaysia for the financial support through the Visiting Scholar (Post-Doctoral) scholarship.

Conflicts of Interest: The authors declare no conflict of interest. 


\section{References}

1. Zhou, J.; Hassan, M.Z.; Guan, Z.; Cantwell, W.J. The low velocity impact response of foam-based sandwich panels. Compos. Sci. Technol. 2012, 72, 1781-1790. [CrossRef]

2. Hassan, M.; Guan, Z.; Cantwell, W.; Langdon, G.; Nurick, G. The influence of core density on the blast resistance of foam-based sandwich structures. Int. J. Impact. 2012, 50, 9-16. [CrossRef]

3. Hassan, M.; Cantwell, W. The influence of core properties on the perforation resistance of sandwich structures-an experimental study. Compos. Part B Eng. 2012, 43, 3231-3238. [CrossRef]

4. Enayati, M.S.; Behzad, T.; Sajkiewicz, P.; Bagheri, R.; Ghasemi-Mobarakeh, L.; Pierini, F. Theoretical and experimental study of the stiffness of electrospun composites of poly (vinyl alcohol), cellulose nanofibers, and nanohydroxy apatite. Cellulose 2018, 25, 65-75. [CrossRef]

5. Enayati, M.S.; Neisiany, R.E.; Sajkiewicz, P.; Behzad, T.; Denis, P.; Pierini, F. Effect of nanofiller incorporation on thermomechanical and toughness of poly (vinyl alcohol)-based electrospun nanofibrous bionanocomposites. Theor. Appl. Fract. Mec. 2019, 99, 44-50. [CrossRef]

6. Ibrahim, M.I.; Dolah, R.; Zuhri, M.; Sharif, S.; Hassan, M. Chemical treatment evaluation of tensile properties for single Kenaf fiber. J. Adv. Res. Appl. Mech. 2016, 32, 9-14.

7. Hassan, M.Z.; Sapuan, S.; Roslan, S.A.; Sarip, S. Optimization of tensile behavior of banana pseudo-stem (Musa acuminate) fiber-reinforced epoxy composites using response surface methodology. J. Mater. Res. Technol. 2019, 8, 3517-3528. [CrossRef]

8. Alaaeddin, M.; Sapuan, S.; Zuhri, M.; Zainudin, E.; AL-Oqla, F.M. Physical and Mechanical Properties of Polyvinylidene Fluoride-Short Sugar Palm Fiber Nanocomposites. J. Clean. Prod. 2019, 235, 473-482. [CrossRef]

9. Khan, Z.; Yousif, B.; Islam, M. Fracture behaviour of bamboo fiber-reinforced epoxy composites. Compos. Part B Eng. 2017, 116, 186-199. [CrossRef]

10. Cai, M.; Takagi, H.; Nakagaito, A.N.; Li, Y.; Waterhouse, G.I. Effect of alkali treatment on interfacial bonding in abaca fiber-reinforced composites. Compos. Part A Appl. Sci. Manuf. 2016, 90, 589-597. [CrossRef]

11. Manalo, A.C.; Wani, E.; Zukarnain, N.A.; Karunasena, W.; Lau, K.-t. Effects of alkali treatment and elevated temperature on the mechanical properties of bamboo fiber-polyester composites. Compos. Part B Eng. 2015, 80, 73-83. [CrossRef]

12. Raghavendra Rao, H.; Varada Rajulu, A.; Ramachandra Reddy, G.; Hemachandra Reddy, K. Flexural and compressive properties of bamboo and glass fiber-reinforced epoxy hybrid composites. J. Reinf. Plast. Compos. 2010, 29, 1446-1450. [CrossRef]

13. Nirmal, U.; Lau, S.T.; Hashim, J. Interfacial adhesion characteristics of kenaf fibers subjected to different polymer matrices and fiber treatments. J. Compos. 2014, 2014, 350737. [CrossRef]

14. Vardhini, K.; Murugan, R.; Selvi, C.; Surjit, R. Optimization of alkali treatment of banana fibers on lignin removal. Indian J. Fibre Text. Res. 2016, 41, 156-160.

15. Kim, I.; Han, J.-I. Optimization of alkaline pretreatment conditions for enhancing glucose yield of rice straw by response surface methodology. Biomass Bioenerg. 2012, 46, 210-217. [CrossRef]

16. Singh, V.K.; Mukhopadhyay, S.; Das, D. Recipe optimization for sugarcane bagasse fiber-reinforced soy protein biocomposite. Indian J. Fibre Text. Res. 2017, 42, 132-137.

17. Mishra, S.; Mohanty, A.; Drzal, L.; Misra, M.; Parija, S.; Nayak, S.; Tripathy, S. Studies on mechanical performance of biofiber/glass reinforced polyester hybrid composites. Compos. Sci. Technol. 2003, 63, 1377-1385. [CrossRef]

18. Jayabal, S.; Sathiyamurthy, S.; Loganathan, K.; Kalyanasundaram, S. Effect of soaking time and concentration of $\mathrm{NaOH}$ solution on mechanical properties of coir-polyester composites. Bullet. Mater. Sci. 2012, 35, 567-574. [CrossRef]

19. Li, Y.; Jiang, L.; Xiong, C.; Peng, W. Effect of different surface treatment for bamboo fiber on the crystallization behavior and mechanical property of bamboo fiber/nanohydroxyapatite/poly (lactic-co-glycolic) composite. Ind. Eng. Chem. Res. 2015, 54, 12017-12024. [CrossRef]

20. Hassan, M.Z.; Sapuan, S.; Rasid, Z.A.; Nor, A.F.M.; Dolah, R.; Md Daud, M.Y. Impact damage resistance and post-impact tolerance of optimum banana-pseudo-stem-fiber-reinforced epoxy sandwich structures. Appl. Sci. 2020, 10, 684. [CrossRef] 
21. ASTM International. ASTM International. ASTM D638-14. In Standard Test Method for Tensile Properties of Plastics; ASTM International: West Conshohocken, PA, USA, 2014. [CrossRef]

22. Zuhri, M.; Guan, Z.; Cantwell, W. The mechanical properties of natural fiber based honeycomb core materials. Compos. Part B Eng. 2014, 58, 1-9. [CrossRef]

23. ASTM International. ASTM International. ASTM C365/365M-16. In Standard Test Method for Flatwise Compressive Properties of Sandwich Cores; ASTM International: West Conshohocken, PA, USA, 2016. [CrossRef]

24. Rout, J.; Misra, M.; Tripathy, S.; Nayak, S.; Mohanty, A. The influence of fiber treatment on the performance of coir-polyester composites. Compos. Sci. Technol. 2001, 61, 1303-1310. [CrossRef]

25. El-Shekeil, Y.; Sapuan, S.; Khalina, A.; Zainudin, E.; Al-Shuja'a, O. Effect of alkali treatment on mechanical and thermal properties of Kenaf fiber-reinforced thermoplastic polyurethane composite. J. Therm. Anal. Calorim. 2012, 109, 1435-1443. [CrossRef]

26. Zikri, M.; Ridzuan, M.; Majid, M.A.; Afendi, M.; Basaruddin, K. Effects of fiber loading and moisture absorption on the tensile properties of hybrid Napier/glass/epoxy composites. J. Phys. Conf. 2017, 1, 012014. [CrossRef]

27. Girisha, C.; Sanjeevamurthy, G.; Srinivas, G. Sisal/coconut coir natural fibers-epoxy composites: Water absorption and mechanical properties. Int. J. Eng. Innov. Technol. 2012, 2, 166-170.

28. Misra, S.; Misra, M.; Tripathy, S.; Nayak, S.; Mohanty, A. The influence of chemical surface modification on the performance of sisal-polyester biocomposites. Polym. Compos. 2002, 23, 164-170. [CrossRef]

29. Oushabi, A.; Sair, S.; Hassani, F.O.; Abboud, Y.; Tanane, O.; El Bouari, A. The effect of alkali treatment on mechanical, morphological and thermal properties of date palm fibers (DPFs): Study of the interface of DPF-Polyurethane composite. S. Afr. J. Chem. 2017, 23, 116-123. [CrossRef]

30. Joglekar, A.; May, A. Product excellence through design of experiments. Cereal Foods World 1987, 32, 857-868. [CrossRef]

31. Manzato, L.; Takeno, M.L.; Pessoa-Junior, W.A.G.; Mariuba, L.A.M.; Simonsen, J. Optimization of cellulose extraction from jute fiber by Box-Behnken design. Fibers Polym. 2018, 19, 289-296. [CrossRef]

32. Qiu, P.; Cui, M.; Kang, K.; Park, B.; Son, Y.; Khim, E.; Jang, M.; Khim, J. Application of Box-Behnken design with response surface methodology for modeling and optimizing ultrasonic oxidation of arsenite with $\mathrm{H}_{2} \mathrm{O}_{2}$. Open Chem. 2014, 12, 164-172. [CrossRef]

33. Wu, L.; Yick, K.-L.; Ng, S.-P.; Yip, J. Application of the Box-Behnken design to the optimization of process parameters in foam cup molding. Expert Syst. Appl. 2012, 39, 8059-8065. [CrossRef]

34. Sari, N.H.; Wardana, I.; Irawan, Y.S.; Siswanto, E. The effect of sodium hydroxide on chemical and mechanical properties of corn husk fiber. Orient. J. Chem. 2017, 33, 3037-3042. [CrossRef]

35. Abu, M.L.; Nooh, H.M.; Oslan, S.N.; Salleh, A.B. Optimization of physical conditions for the production of thermostable T1 lipase in Pichia guilliermondii strain SO using response surface methodology. BMC Biotechnol. 2017, 17, 78. [CrossRef] [PubMed]

36. Rauf, M.; Marzouki, N.; Körbahti, B.K. Photolytic decolorization of Rose Bengal by UV/ $\mathrm{H}_{2} \mathrm{O}_{2}$ and data optimization using response surface method. J. Hazard. Mater. 2008, 159, 602-609. [CrossRef]

37. Ammayappan, L.; Shakyawar, D.; Gupta, N. Optimization of dyeing condition for wool/cotton union fabric with direct dye using Box-Behnken design. Fibers Polym. 2011, 12, 957. [CrossRef]

38. Karthikeyan, K.; Nanthakumar, K.; Shanthi, K.; Lakshmanaperumalsamy, P. Response surface methodology for optimization of culture conditions for dye decolorization by a fungus, Aspergillus niger HM11 isolated from dye affected soil. Iran J. Microbiol. 2010, 2, 213.

39. Fu, J.; Zhao, Y.; Wu, Q. Optimising photoelectrocatalytic oxidation of fulvic acid using response surface methodology. J. Hazard. Mater. 2007, 144, 499-505. [CrossRef]

40. Zhang, K.; Wang, F.; Liang, W.; Wang, Z.; Duan, Z.; Yang, B. Thermal and mechanical properties of bamboo fiber-reinforced epoxy composites. Polymers 2018, 10, 608. [CrossRef]

41. Asim, M.; Jawaid, M.; Abdan, K.; Nasir, M. Effect of alkali treatments on physical and mechanical strength of pineapple leaf fibers. IOP Conf. Ser. Mater. Sci. Eng. 2018, 290, 012030. [CrossRef]

42. Wang, F.; Zhou, S.; Yang, M.; Chen, Z.; Ran, S. Thermo-mechanical performance of polylactide composites reinforced with alkali-treated bamboo fibers. Polymers 2018, 10, 401. [CrossRef]

43. Qian, S.; Mao, H.; Sheng, K.; Lu, J.; Luo, Y.; Hou, C. Effect of low-concentration alkali solution pretreatment on the properties of bamboo particles reinforced poly (lactic acid) composites. J. Appl. Polym. Sci. 2013, 130, 1667-1674. [CrossRef] 
44. Kushwaha, P.K.; Kumar, R. Effect of silanes on mechanical properties of bamboo fiber-epoxy composites. J. Reinf. Plast. Compos. 2010, 29, 718-724. [CrossRef]

45. Yamashita, M.; Gotoh, M. Impact behavior of honeycomb structures with various cell specifications-Numerical simulation and experiment. Int. J. Impact. 2005, 32, 618-630. [CrossRef]

46. Hazizan, M.A.; Cantwell, W. The low velocity impact response of an aluminium honeycomb sandwich structure. Compos. Part B Eng. 2003, 34, 679-687. [CrossRef] 